\title{
“Küçük Uyuşmazlıkların (Small Claims)” Kendine Özgü Bir Prosedür Dâhilinde Çözümlenmesine İlişkin Düşünceler
}

\author{
Considerations for the Resolution of "Small Claims" in a Sui Generis \\ Procedure
}

\section{Kâmil Yıldırım* (D), Mehmet Akif Gül ${ }^{*}$}

\section{öz}

Belirli değerin altındaki uyuşmazlıkların yazılı yargılama usûlü dâhilinde çözümlenmesinin adalete erişim özelinde pek çok olumsuz yönü vardır. Yazılı yargılama usûlünün nispeten pahalı ve yavaş olması, bireylerin "küçük uyuşmazlık (small claims)" olarak nitelendirilebilecek uyuşmazlıklarda hak arama motivasyonunu düşürmektedir. Ayrıca bu uyuşmazlıkların yazılı yargılama usûlü dâhilinde çözümlenmesi, mahkemelerin iş yükünü de artırmakta ve yargının daha yavaş işlemesine neden olmaktadır. Bu makalede, bazı mukayeseli hukuk sistemlerinde belirli değerin altındaki uyuşmazlıkların ne şekilde çözümlendiği irdelenecek ve hukukumuz bakımından genel hatları çizilen bir sisteme dair düşüncelerimiz paylaşılacaktır.

Anahtar Kelimeler: Dava değeri, Küçük uyuşmazlıklar, Yargılama usûlü, Adalete erişim, Medenî yargi.

\section{ABSTRACT}

Resolving disputes below certain values within the written jurisdiction has many negative aspects in the way of access to justice. The relatively expensive and slow method of written trials reduces the motivation of individuals to seek rights in disputes that can be described as "small claims". In addition, resolving these disputes within the written judicial procedure increases the workload of the courts and causes the judiciary to function more slowly. In this article, how disputes below certain value are resolved in some comparative legal systems will be examined and our considerations on a system that is outlined in terms of our law will be shared.

Keywords: Value in dispute, Small claims, Proceeding, Access to justice, Civil procedure.

\section{GiRiş}

Hukuk sistemimizin temel sorunlarından biri de yargılamaların uzun sürmesi ve bireylerin tabir-i caiz ise adliye kapılarında hak dilenen bir pozisyona gelmeleridir. Esasen yargılamanın hızlandırılması meselesi yalnızca ülkemizin değil pek çok başka ülkenin de adalet politikasının temel sorularından

\footnotetext{
* $\quad$ Marmara Üniversitesi Hukuk Fakültesi Medenî Usûl ve İcra - İflâs Hukuku Anabilim Dalı, ORCID: 0000-0003-4764-6805.

** Marmara Üniversitesi Hukuk Fakültesi Medenî Usûl ve İcra - İflâs Hukuku Anabilim Dalı mehmet.akif@marmara.edu.tr, ORCID: 0000-0002-7324-0094
}

Sorumlu Yazar/Correspondence Author: M. Kâmil Yıldırım

E-posta/E-mail: kamilyildirim@marmara.edu.tr

Geliş Tarihi/Received: $\quad$ 27.08.2021 Kabul Tarihi/Accepted: $\quad 18.11 .2021$ 
birini oluşturmaktadır ${ }^{1}$. Bu meyanda, pek çok ülkede belirli değerin altındaki uyuşmazlıkların basitleştirilmiş prosedürler dâhilinde çözümlenmesine ilişkin imkânlar getirilmiştir. Hukukumuzda ise böyle bir imkândan bahsedilememektedir. Bu makalede, öncelikle dava değeri ile temel haklar ve yargılama usûlü arasındaki ilişki ayrı ayrı ele alınacak; akabinde, mukayeseli hukuktaki bazı özel prosedürler incelenerek bunların genel hatları ortaya konulacaktır.

\section{DAVA DEĞERININ TEMEL HAKLAR ILE íLişKISi}

Belirli değerin altındaki uyuşmazlıkların özel bir prosedür dâhilinde çözümlenmesine ilişkin değerlendirmede bulunmadan önce, bu yönde bir çözümün temel haklar ve anayasal düzenlemeler ile ilişkisi hususu ele alınacaktır. Nitekim yalnızca uyuşmazlık çözüm prosedürünün hızlandırılması yeterli olmayıp bunun adalete erişimi de tesis etmesi gerekliliği vardır.

"Hak arama özgürlüğ̈̈", Anayasanın 36. maddesinde düzenlenmiş olup herkesin meşru vasıta ve yollardan faydalanmak suretiyle yargı mercileri önünde davacı veya davalı sıfatıyla iddia ve savunmada bulunabileceğini ve âdil yargılanma hakkına sahip olduğunu ifade etmektedir. Bu kavram soyut, genel ve objektif nitelik taşımakta ve anayasal temeli haiz bir hakkı ifade etmektedir. Bu hak, uyuşmazlığın ortaya çıkmasından önce de mevcuttur ve yalnızca vatandaşların değil herkesin sahip olduğu yargısal bir temel haktır. Bu hakkın uyuşmazlık çıktıktan sonra somut hâle gelmesiyle birlikte "hukukî korunma talebi" ortaya çıkmaktadır. Özellikle devlet yargısına başvurulduğu andan itibaren, bu talebin karşılanması gerekli ve zorunludur. Hukukî korunma talebi, bir hakkın somut olarak kullanılmasını ifade ederken, bu hakkın gerçekten etkili, düşük masraf ile, basit ve kolay bir şekilde kullanılabilmesi, "adalete erişim (mahkemeye erişim)" kavramı dâhilinde değerlendirilmektedir. Bahsedilen bu üç kavramın birbiriyle bağlantısı şu şekilde özetlenebilir: Hak arama özgürlüğü, soyut, genel ve objektif bir hakkı; hukukî korunma talebi, bu hakkın somut olarak karşılanmasını; adalete erişim (mahkemeye erişim) ise hakkın etkin kullanımını sağlayan mekanizmayı içeren bir bütünün varlı̆̆ını ifade etmektedir².

1 Avrupa Birliği üyesi ülkelerdeki sınır ötesi küçük uyuşmazlıkların çözümü için öngörülen prosedür hakkında genel bilgi için bkz. İbrahim Barış Sayar, 'Avrupa Basit Hak İddiaları Prosedürü (European Small Claims Procedure): Kapsamı ve Uygulanması Üzerine Bir İnceleme’, (2018) XXII (1), Ankara Hacı Bayram Veli Üniversitesi Hukuk Fakültesi Dergisi 4994. Ayrıca bkz. Mustafa Serdar Özbek, 'Avrupa Konseyince Adalet Hizmetlerinin Etkinliğinin Artırılması İçin Öngörülen Tedbirler', (2006) 55 (1) Ankara Üniversitesi Hukuk Fakültesi Dergisi 207-292.

2 Hakan Pekcanıtez, 'Medenî Usûl Hukukuna İlişkin Genel Bilgiler' iç Hakan Pekcanıtez, Muhammet Özekes, Mine Akkan ve Hülya Taș - Korkmaz (edr), Pekcanıtez Usûl Medenî Usûl Hukuku (15. Bası, Oniki Levha Yayıncılık 2017) 22-24. Sungurtekin-Özkan, adalete erişim kavramını şu şekilde tanımlamaktadır: "toplumu oluşturan bireylerin, insan hakları, temel hak ve özgürlükler ve adaletin kalitesinden ödün vermemek koşuluyla, en kolay, hızl, etkili ve en az masrafla uygun hukuki mekanizmalardan yararlanarak, ihtiyaç duydukları hukuki çözümlere ulaşması”. Bkz. Meral Sungurtekin-Özkan, 'Anayasal Şikayet ve Adalete Erişim', (2014), 16 (Özel Sayı) Dokuz Eylül Üniversitesi Hukuk Fakültesi Dergisi (Prof. Dr. Hakan PEKCANITEZ’e Armağan) 399-410, 401. Birleşmiş Milletler Kalkınma Programı (United Nations Development Programme - UNDP), adalete erişim kavramını şu şekilde tanımlamaktadır: "toplumu oluşturan bireylerin, insan hakları standartlarına uygun olarak, geleneksel ya da geleneksel olmayan yollardan, ihtiyaç duydukları hukuki çözümlere ulaşabilecek durumda olmalarıdır". Ayrıca, adalete erişimin demokratik devlet yönetimi ve yoksullukla mücadele ile güçlü bağları olduğu işaret edilmektedir. Bkz. Sungurtekin-Özkan (n 3) 401. 
Bir temel hak olan adalete erişim (mahkemeye erişim) hakkına bazı sınırlamalar getirilebilir. Ancak bu sınırlamaların kişinin AİHS ile tanınan haklarının özüne zarar verici nitelikte olmaması gereklidir. AİHM, bu yöndeki bir sınırlamanın ihlâl niteliği taşıyıp taşımayacağı değerlendirmesini yaparken faydalanılacak ölçütleri Ashingdane vs. Birleşik Krallık kararında tespit etmiştir. Bu karara göre, mahkemeye erişim hakkının ihlâl edilmemesi için şu unsurların bir arada olması gereklidir³:

- Sınırlamanın hakkın özüne zarar vermemesi

- Meşru bir amaç güdülmesi

- Hedeflenen meşru amaç ile başvurulan araçlar arasında makûl bir orantının bulunması

Hukukumuzda temel hak ve özgürlüklerin ne şekilde sınırlandırılabileceği Anayasanın 13. maddesinde düzenlenmiştir. Buna göre, "temel hak ve hürriyetler, özlerine dokunulmaksızın yalnızca Anayasanın ilgili maddelerinde belirtilen sebeplere bağh olarak ve ancak kanunla sınırlanabilir. Bu sinırlamalar, Anayasanın sözüne ve ruhuna, demokratik toplum düzeninin ve lâik Cumhuriyetin gereklerine ve ölçülülük ilkesine aykırı olamaz.". Görüleceği üzere, AİHM’nin Ashingdane vs. Birleşik Krallık kararında tespit edilen unsurlara paralel bir anayasal düzenleme hukukumuzda da mevcuttur.

Dava değerinin temel haklar ile olan bağlantısı, yukarıdaki unsurlar göz önünde bulundurularak açılklanabilmektedir. Dava değerine dayalı olarak kişinin adalete erişim (mahkemeye erişim) hakkının çeşitli şekillerde sınırlandırılması, bu sınırlamanın meşru bir amaca hizmet etmesi, hakkın özüne zarar vermemesi ve meşru amaç ile sınırlama aracı arasında makûl bir orantının (ölçülülüğün) bulunması hâlinde mümkündür.

$\mathrm{Bu}$ açılklamalar ışı̆̆ında, belirli değerin altındaki uyuşmazlıkların özel bir prosedür dâhilinde çözümlenmesine ilişkin bir değerlendirmede bulunurken dikkat edilmesi gereken en önemli husus, kişinin hâkim önüne çıkabilmesi imkânının tamamen ortadan kaldırılmamasıdır. Diğer bir ifadeyle, bazı prosedürel sinırlamalar öngörülse dahi, yargılamanın bir hâkim tarafından yürütülmesi noktasında esnek düzenlemeler yapılmasından kaçınılmalıdır. Çalışmanın ilerleyen bölümünde inceleyeceğimiz mukayeseli hukuktaki düzenlemeler dikkate alındığında, bu hususta esneklik gösterilmesinden kaçınıldığı gözlemlenmektedir. Bununla birlikte, öngörülen prosedür dâhilinde getirilen sınırlandırmaların hakkın özüne zarar vermemesi, meşru bir amaca hizmet etmesi ve hedeflenen bu amaç ile başvurulan araçlar arasında makûl bir orantının bulunması her durumda göz önünde bulundurulmalı ve ayrıca değerlendirilmelidir. Örneğin, öngörülen özel prosedür dâhilinde

3 Kararın ilgili bölümü şu șekildedir: "Șüphesiz mahkemeye erişim hakkı mutlak değildir ve bazı sınırlamalara tâbi tutulabilir. Devletlerin, mahkemeye erişim hakkı bakımından, toplumun ve bireylerin ihtiyaçları göz önüne alınarak doğası gereği yer ve zamana göre değişkenlik gösterebilecek düzenlemeler yapabilmesi için bu mümkün olmalıdır. Üye devletler, bu yönde düzenlemeler yaparken belirli bir takdir marjina sahiptir. Sözleşmenin gerekliliklerinin yerine getirilip getirilmediğine dair nihâ̂ karar Mahkemenin denetiminde olsa da, mahkeme, devletlerin bu alandaki en iyi politikanın ne olabileceğine dair değerlendirme işlevinin bir parçası değildir. Bununla birlikte, uygulanan sinırlar, hakkın özünü zedeleyecek şekilde bireyin adalete erişimini ortadan kaldırmamal ya da kısttlamamalidır. Yine, sinırlamanın meşru bir amacı bulunmamaktaysa ve meşru amaç ile bu amaca ulaşmak için kullanılan araç arasında makûl bir oranlılık ilişkisi yoksa Sözleşmenin 6. maddesine uygun bir sinirlandırmadan bahsedilemez.".

Karar için bkz. Ashingdane vs. Birleşik Krallik (1985) App no 8225/78. 
kişinin açıklama ve ispat hakkına dair getirilen sınırlandırmalar, hakkın kullanılmasını olanaksız hâle getirecek düzeyde olmamalıdır.

Burada ele alınması gereken bir diğer husus, özel bir prosedür dâhilinde kanun yoluna başvuru imkânının sınırlanmasının temel haklar ve anayasa düzenlemeleri doğrultusunda ne derece yerinde olacağıdır.

Kanun yoluna başvuru hakkının belirli bir parasal değerle sınırlandırılmasının hak arama özgürlüğü, hukuk devleti ve eşitlik ilkelerine aykırı olduğu iddiasıyla belirtilen sınırlara ilişkin düzenlemelerin iptâli talebi Anayasa Mahkemesi önüne taşınmış; Anayasa Mahkemesi, kanun yoluna başvuru hakkının bu şekilde sınırlandırılmasını Anayasaya aykırı bulmamıştır. Anayasa Mahkemesi, kararında özetle şu gerekçelendirmelerde bulunmuştur ${ }^{4}$ :

- Kamu yararı gerektirdiğinde, bazı hükümler için kanun yollarına başvurmanın engellenmesi mümkündür.

- Hukuk mahkemelerinin bazı kararları için kanun yoluna başvurulması yolunun kapatılmasına ilişkin düzenleme, hukuk devleti kavramıyla bağdaşmayacak sonuçlara yol açma ihtimâli doğuran bir nitelik arz etmedikçe bu kavramla çelişkiye düşmez.

- Kanun yoluna başvurunun sınırlandırılmasına ilişkin düzenleme ile, davaların hızlandırılması ve kanun yolu mahkemesinin iş yükünün bir ölçüde azaltılması amaçlanmıştır.

- Kanun yoluna başvurunun sınırlandırılmasına ilişkin düzenleme ile, varlıklı kimseler ile iktisaden güçsüz olanlar arasında herhangi bir ayrım yapılmamıştır. Diğer bir ifadeyle, tüm vatandaşlar aynı hükme tâbi tutulmuştur.

- Kesin karardan varlıklı kimselerin daha az etkilenecek olması, Anayasanın sosyal devlet ilkesine ve eşitlik kurallarına aykırılık nedceni olarak kabul edilemez.

- Anayasa'da bütün mahkeme kararlarının denetime tâbi kılınmasını öngören bir hüküm bulunmamaktadır.

- İlk derece mahkemelerinin tüm kararlarının denetlenmesini istemek, ilk derece hâkimlerine güvensizlik anlamına gelir ki bunun hiçbir haklı nedeni olamaz.

Anayasa Mahkemesi’nin bu kararı, öğretide bir kısım yazarlar tarafından çeşitli yönleriyle eleştirilmiştir. Bu eleştiriler, kararın daha çok Yargıtayın iş yükünü dikkate alması; hak arama özgürlügü bakımından dar bir yorumun benimsenmesi; kararın kanun yolunun amacı ve Anayasal ilkeler ile bağdaşmaması şeklinde gerekçelendirilmektedir ${ }^{5}$.

4 Kararın tam metni için bkz. RG, 16.04.1986, S.19080, 18-28. Kararın değerlendirilmesi için bkz. Selçuk Öztek, 'HUMK m.427'deki Kesinlik Sınırının Temyiz Kanun Yolunun Amacı Bakımından Değerlendirilmesi ve Anayasa Mahkemesinin 10.1.1986 Tarihli Kararı', (1987) 21 (2), Marmara Üniversitesi Hukuk Araştırmaları Dergisi 62-74.

5 Eleştiriler için bkz. Öztek (n 5) 68; Yavuz Alangoya, 'Kanun Yolunun Anayasal Temeli ve HUMK m.427 Hükmü ile Kanun Yolu Kapatılmış Olan Kararlara Karşı Kanun Yoluna Müracaat İmkanı’, iç Hakan Pekcanıtez (ed), 75. Yaş 
Kanaatimizce, Anayasa Mahkemesi’nin yukarıda değinilen kararı, gerekçesi bakımından eleştiriye açıktır. Nitekim, kanun yolu mahkemesinin iş yükü ve kamu düzeni yönündeki gerekçeler, devletin adalet mekanizmasını işler şekilde tesisi ile ilgili olup bireyin mahkemeye erişim hakkının ölçülü şekilde sınırlandırılması ile doğrudan bağlantılı sayılamaz. Bununla birlikte, başvuru sınırına ilişkin açıklamalar sübjektif değerlendirmeler olup bireyin hukukî korunma ihtiyacının dava konusunun değeri esas alınarak farklı değerlendirmeye tâbi tutulmaması gerekir. İlgili sınırlamanın AİHM’nin öngördüğü ve Anayasanın 13. maddesinde düzenlenen temel hak ve özgürlüklerin sinırlandırılması ölçütlerine uygun olduğu kabul edilse dahi6 ${ }^{6}$, bireyin hukukî korunma ihtiyacını önceleyen ve statükonun olumsuz getirilerini azaltabilecek nitelikte düzenlemeler yapılabilmesi mümkündür. Bu meyanda, izne bağlı kanun yolu ${ }^{7}$ sisteminin bir alternatif olarak değerlendirilmesi önerilebilir. Kanun yoluna başvuru hakkının değere dayalı olarak sınırlandırılması, mahkemeye erişim hakkının ihlâli riskinin yanı sıra, kanun yolu yargılamasının amaçlarından birisi olan içtihat birliğinin sağlanması amacına da ters düşmektedir ${ }^{8}$.

Alman hukukunda, değere ve izne bağlı kanun yolu sistemi birlikte uygulanmaktadır. Bu sisteme "karma sistem" adı verilmektedir. Karma sistem, hak arama özgürlügünün daha etkin kullanılmasını ve hukukun gelişimini sağlayacak alternatif bir sistem olarak değerlendirilmektedir 9 .

dZPO \$ 511/2-1 hükmüne göre, değeri 600,00 Avro üzerinde olan uyuşmazlıklar bakımından istinaf kanun yoluna başvurulabilir. $\$ 511 / 2$-2 hükmüne göre ise, ilk derece mahkemesi, kanun yoluna başvurulmasına izin verebilir. $\$ 511 / 4$ hükmüne göre, malvarlığına ilişkin uyuşmazlığın değeri 600,00 Avro üzerinde olmasa dahi, uyuşmazlığın ilkesel değeri sahip olması veya hukukun gelişimi ya da birliğinin sağlanması için istinaf mahkemesinin kararı gerekli olması durumlarında, ilk derece mahkemesi istinafa başvurulmasına izin vermelidir. İstinaf mahkemesi, ilk derece mahkemesinin izin kararı ile bağlıdır ${ }^{10}$.

Günü İçin Prof. Dr. Baki Kuru Armağanı (Türkiye Barolar Birliği Yayınları 2004) 29 vd.; Saim Üstündağ, 'Mukayeseli Hukukta Yargıtay Örnekleri ve Türk Yargıtayı', (1989) 15 (1-4), Yargıtay Dergisi 73 vd., 91; Tolga Akkaya, 'Temyize Başvuru Hakkının Sınırlandırılması ve İzne Bağlı Temyiz Sistemi', iç Osman Berat Gürzumar (ed), Halûk Konuralp Anısına Armağan (Yetkin Yayınları 2009) 71. Türk hukukunda kesinlik sınırına ilişkin düzenlemelerin, kural olarak, mahkemeye erişim hakkına engel teşkil etmediği; hakka getirilen sınırlamanın AİHM tarafından belirlenen ölçütler ile uyumlu olduğu yönünde bkz. Sezin Aktepe-Artık, Medeni Usul Hukukunda Adil Yargılanma Hakkı (Seçkin Yayıncılık 2013) $126 \mathrm{vd}$.

6 Aynı yönde bkz. Aktepe-Artık (n 6) 126.

7 Detaylı bilgi için bkz. Akkaya (n 6) 81 vd. Değere dayalı temyiz sisteminin keyfiliği önleyeceği; bununla birlikte, belirli dava türleri bakımından temyize müracaatı baştan bertaraf edeceği; bu olumsuzluğun izne bağlı temyiz sistemi ile giderilebileceği yönünde bkz. Mehmet Kamil Yıldırım, Hukuk Devletinin Gereği: İstinaf (Nesil Matbaacılık 2000) 8.

8 Öztek (n 5), 68; Yıldırım (n 8), 8-9; Akkaya (n 6), 70; Aktepe-Artık (n 6), 127. İzne bağlı istinaf sisteminin 5236 sayılı Kanun hazırlanırken Bilim Komisyonunda uzun uzadıya tartışıldığı ve özellikle ilk derece mahkemesi hâkimi bakımından yaratacağı sakıncalar dikkate alınarak benimsemediği yönünde bkz. Selçuk Öztek, Türk Medeni Yargılama Hukukunda İstinaf ve Temyiz (Yetkin Yayınları 2021) 100 kn.59.

9 Bkz. Tolga Akkaya, Medenî Usûl Hukuunda İstinaf (Yetkin Yayınları 2009) 118.

10 İstinaf mahkemesi, ilk derece mahkemesinin izin kararı ile bağlı olmakla birlikte, pek doğaldır ki uyuşmazlığa ilişkin maddî ve hukukî değerlendirmelerle bağlı olmayacaktır. Bkz. Hans Joachim Musielak, Grundkurs ZPO (10. Aufl. 2010) 312. 
dZPO $\$ 511 / 4$ hükmünde belirtilen şartları kısaca ele almak gerekirse ${ }^{11}$ :

- Uyuşmazlığın çözümü için önem arz eden hukukî sorun hakkında, daha önce üst mahkeme tarafından emsal bir karar verilmemiş ve bu konuda hukukun yeknesak şekilde uygulanması çoğunluğun hukukî yararı için gerekliyse ilkesel değerin varlığından bahsedilir. Buradaki hukukî sorun, yalnızca uyuşmazlığın taraflarının menfaatleri ile ilgili olmamalıdır.

- Bir hukukî sorun hakkında öğretide fikir birliği bulunmamakta ise, hukukun gelişimi açısından kanun yoluna başvurulması gerekebilir.

- İlk derece mahkemesi, daha önceki kararlarından ya da üst mahkemelerin içtihatlarından farklı yönde bir karar verecek ise, içtihat birliğinin sağlanabilmesi bakımından kanun yoluna başvurulmasına izin verilmelidir.

Hukukumuzda, hukukun gelişimi ve hukuk birliğinin sağlanması amacıyla, HMK’nin 363. maddesinde "kanun yararına temyiz" kurumu kabul edilmiştir. Buna göre, Adalet Bakanlığı veya Yargıtay Cumhuriyet Başsavcılığı, ilk derece mahkemesince kesin olarak verilen kararlar, istinaf incelemesinden geçmeden kesinleşen kararlar, bölge adliye mahkemesi hukuk dairelerinin ilk derece mahkemesi sifatı ile kesin olarak verdikleri kararlar ile yine bu sifatla verilen ve temyiz incelemesinden geçmeden kesinleşen kararlar hakkında, kanun yararına temyiz yoluna başvurabilir. Kanun yararına temyiz talebinin yerinde görülmesi hâlinde, karar Yargıtay tarafından kanun yararına bozulur. Bununla birlikte, bu bozma kararı, aleyhine başvurulan kararın hukukî sonuçlarını ortadan kaldırmaz $^{12}$. Bu yönüyle, kanun yararına temyiz ve izne bağlı istinaf sistemlerinin birbirinin muadili olmadığı ifade edilebilir. Nitekim, kanun yararına temyiz sistemi, hak arama özgürlügünün daha etkin kullanımına hizmet etmemektedir; yalnızca hukukun gelişimi ve hukuk birliğinin sağlanması hususlarında izne bağlı istinaf sistemine benzer özellikler göstermektedir ${ }^{13}$.

Kanun yoluna başvuru hakkına ilişkin yukarıdaki açıklamalarımız, belirli değerin altında uyuşmazlıkların özel bir prosedür dâhilinde çözümlenmesi hususunda da dikkate alınmalıdır. Bu meyanda, öngörülen prosedürün kanun yoluna başvuruyu tamamen kaldırmamakla birlikte, Alman hukukuna paralel şekilde, bu hakkın belirli ölçütlere dayalı olarak izne tabî kılması düşünülebilir.

Belirli değerin altındaki uyuşmazlıkların özel bir prosedür dâhilinde çözümlenmesinin temel haklar ve anayasal düzenlemeler ışı̆̆ında olumlu getirileri de bulunmaktadır. Nitekim, çalışmanın ilerleyen

11 Detaylı bilgi için bkz. Akkaya (n 10) 118 dn.227'deki yazarlar..

12 Kanun yararına temyiz üzerine bozma kararı verilmesi hâlinde, ilk derece mahkemesi kararının hukukî sonuçlarının ortadan kalkmamasının eleştirisi için bkz. Necip Bilge ve Ergun Önen, Medenî Yargılama Hukuku Dersleri (Sevinç Matbaasi 1978) 648.

13 Akkaya (n 10) 119. Kanun yararına temyiz kurumu düzenlenirken, Kanun Komisyonunda ileri sürülen görüş şu ifadelerle ortaya konulmaktadır: Tasarı m.327 ve 328 ile ilgili ortak bir konu olarak, sadece değere dayalı temyiz esasının kabulünün sakıncalı olabileceği, cüzi değere sahip veya verildiğinde kesin olan kararlara karşı da, ileride emsal teşkil etmesi ihtimali olan kararlar bakımından veya kanun maddesine yeni bir yorum getiren temyiz mahkemesi kararlarına da temyiz yolunun açık tutulması gerektiği görüşü Komisyon’da dile getirilmiştir.”. Naklen: Yıldırım (n 8) 138. 
bölümünde açıklanacağı üzere, bu prosedür dâhilinde yargılama giderlerinin sınırlandırılması, daha az masraflı bir yargılamaya erişimi mümkün kılacak ve adalete erişimi artıracaktır ${ }^{14}$.

\section{DAVA DEĞERi iLE YARGILAMA USÛLÜ íLişKISi}

Hukuk yargılamamızda hâli hazırda "basit yargılama usûlü" ve "yazılı yargılama usûlü" olmak üzere iki farklı yargılama usûlü mevcuttur. Bu iki usûl arasındaki en çarpıcı fark, dilekçeler teatisi aşamasında verilecek dilekçelerin sayısı ile iddianın ve savunmanın genişletilmesi veya değiştirilmesi yasağının başlayacağı ân olarak belirlenebilir. HMK’nin 319. maddesine göre, basit yargılama usûlüne tâbi davalarda, iddianın genişletilmesi veya değiştirilmesi yasağı dava açılmasıyla; savunmanın genişletilmesi veya değiştirilmesi yasağı cevap dilekçesinin mahkemeye verilmesiyle başlayacaktır ${ }^{15}$.

Basit yargılama usûlünün uygulanacağı dava ve işler, HMK'nin 316. maddesinde düzenlenmiştir. $\mathrm{Bu}$ madde kapsamında, belirli değerin altındaki uyuşmazlıklarda basit yargılama usûlünün uygulanacağına ilişkin genel bir düzenleme yapılmamıştır. Bununla birlikte, HMK’nin 316/1-g maddesinde, diğer kanunlarda yer alan ve yazılı yargılama usûlünün dışındaki yargılama usûllerinin uygulanacağı belirtilen dava ve işlerde basit yargılama usûlünün uygulanacağı düzenlenmiştir.

İsviçre’de, sZPO \$ 243/1 hükmüne göre, malvarlığına ilişkin uyuşmazlıklardan değeri 30.000,00 İsviçre frangına kadar olanlarda basit yargılama usûlü uygulanır (vereinfachte Verfahren). Bu kuralın istisnaları ise sZPO $\$ 243 / 2-3$ hükümlerinde belirlenmiştir ${ }^{16}$.

İsviçre’de yargılama usûlüne ilişkin değer sınırlaması, basit yargılama usûlünü düzenleyen sZPO \$ 243 hükmü ile malvarlığına ilişkin uyuşmazlıklar için genel olarak uygulanan bir düzenleme şeklinde getirilmiştir. sZPO $\$ 243 / 3$ hükmünde ise, $\$ 6$ düzenlemesine göre yalnızca kantonal düzeydeki ticarî uyuşmazlıklar için kurulan özel mahkemelerde (ticaret mahkemesi), yargılama usûlündeki değer sınırına ilişskin bu hükmün uygulanmayacağı düzenlenmiştir.

Almanya’da ise, dZPO \$495a hükmüne göre, mahkeme, 600,00 - Avro tutarının altındaki uyuşmazlıklarda, Bagatellverfahren olarak ifade edilen bir usûlün uygulanması konusunda takdir yetkisini haizdir ${ }^{17}$.

14 Yargılama masraflarının tutarı ile AİHS’nin 6. maddesi arasındaki bağlantı hususunda, AİHM tarafından verilen bazı örnek kararlar için bkz. Kreuz vs. Polonya (2001) App no 28249/95; Tunçvs. Türkiye (2008) App no 20400/03.

15 Genel olarak bkz. Mehmet Kâmil Yıldırım, 'Teksif ve Sözlülük İlkeleri Açısından Yargılama Usulleri Hakkında Düşünceler’ iç Selçuk Öztek, M. Kamil Yıldırım ve Nevhis Deren - Ylldırım (edr), Prof. Dr. Ergun ÖNEN’e Armağan (Alkım 2003) $467 \mathrm{vd}$.

16 Samuel Rickli, Der Streitwert im schweizerischen Zivilprozessrecht (Dike 2014) 15, Rdnr.31.

17 Almanyảda basit yargılama usûlüne dair genel bir düzenleme bulunmamakla birlikte, "basit yargılama şekli" olarak ifade edilebilecek yargılama şekilleri kabul edilmiştir. dZPO $\$ 495$ a hükmünde düzenlenen yargılama şekli de bunlardan biri niteliğindedir. Bu yargılama usûlü, yalnızca sulh mahkemelerinde uygulanabilir niteliktedir. Bkz. Gülcan Sunar, 'Medeni Usul Hukukunda Basit Yargılama Usulü' (Doktora Tezi, Marmara Üniversitesi 2002) 17; Hans Peter Mayer, Julia Lindemann and Georg Haibach, Small Claims Verordnung (C.H. Beck 2009), 9-11. 
Görüleceği üzere gerek İsviçre gerekse Alman usûl kanunlarında, belirli değerin altındaki uyuşmazlıklarda basit yargılama usûlünün uygulanmasına ilişkin özel bir hüküm getirilmiştir. Bazı ülkelerde ise, aşağıda inceleneceği üzere, "küçük uyuşmazlıklar (small claims)" olarak tabir edilen dava ve işler hakkında özel prosedürler öngörülmüştür.

Hukukumuzda, malvarlığına ilişkin uyuşmazlıklarda genel olarak uygulama alanı bulacak benzer bir düzenleme mevcut değildir. Bununla birlikte, TTK’nin 4/2. maddesine göre, miktar veya değeri beşyüzbin Türk Lirasını geçmeyen ticarî davalarda basit yargılama usûlü uygulanır ${ }^{18}$. Bu özel hüküm, yalnızca ticarî davalar ${ }^{19}$ bakımından getirilmesi yönüyle eleştiriye açık niteliktedir. Nitekim, yargılama usûlünün dava değerine bağlı şekilde değişkenlik göstermesi noktasında, ticarî davalar ile diğer davalar arasında nasıl bir ayrım gözetildiği anlaşılamamaktadır. Örneğin, 490.000,00 - TL değerindeki ticarî bir dava için basit yargılama usûlü uygulanmaktayken, 100,00 - TL değerindeki bir alacak davası için yazılı yargılama usûlünün uygulanması söz konusudur. Bu durum, gerekçesi anlaşılamayan bir çelişki yaratmaktadır. Kanaatimizce, uyuşmazlığın ticarî olup olmaması fark etmeksizin belirli değerin altındaki davalarda yazılı yargılama usûlünün uygulanmaması yerinde olacaktır. Bu şekilde, "küçük uyuşmazlıklar (small claims)" olarak tabir edilen dava ve işlerin daha az masrafla ve daha hızlı şekilde çözümlenmesi mümkün hâle gelebilir.

"Küçük uyuşmazlıklar (small claims)" bakımından belirlenecek bir değere göre basit yargılama usûlünün mü uygulanması gerektiği yoksa bunlara özel basitleştirilmiş bir küçük uyuşmazlık çözüm prosedürünün mü getirilmesi gerektiği cevaplanması gereken diğer bir sorudur. Yukarıda belirtildiği üzere, basit yargılama usûlü ile yazılı yargılama usûlü arasında, uyuşmazlığın çözümünü makûl şekilde hızlandıracak ve masrafları da makûl ölçüde sınırlayacak bir fark bulunmamaktadır. Bu nedenle, belirli değerin altındaki uyuşmazlıklar için basit yargılama usûlünün uygulanmasından ziyade, kendine özgü bir prosedürün getirilmesi daha etkili bir sonuç doğuracaktır. Takip eden başlıklarda, karşılaştırmalı hukuktaki küçük uyuşmazlık çözüm prosedürleri incelenecek ve bu prosedürlerin yargılamayı hızlandırmak ve masrafları azaltmak adına öne çıkan yönleri değerlendirilerek muhtemel bir küçük uyuşmazlık çözüm prosedürü düzenlemesine dair düşüncelerimiz aktarılacaktır.

Uygulanacak yargılama usûlünün dava değerine göre değişiklik göstermesi, cevaplanması gereken çeşitli soruları da beraberinde getirmektedir. Başlangıçta yargılama usûlüne dair değer sınırının altında kalmakla birlikte, davanın sslahı ile ya da belirsiz alacak davasında talep sonucunun artırımı ile yargılama usûlüne ilişkin değer sınırının üzerine çıkılması hâlinde, yargılama usûlleri arasındaki farklardan kaynaklanan çeşitli usûlî sorunlara çözüm getirilmesi gerekir. Bu durumun tersi de mümkün olabilir. Nitekim, başlangıçta yazılı yargılama usûlüne tâbi olacak bir talep sonucu oluşturmakla birlikte, cevaba cevap dilekçesinde talep sonucunun Kanunda öngörülen değerin altına düşürülmesi durumunda, basit yargılama usûlüne tâbi olması gereken bir davada yazılı yargılama

18 İlgili madde, 28.02.2018 tarih ve 7101 sayılı Kanunun 61. maddesiyle mevzuatımıza girmiştir. Bu değer, başlangıçta yüzbin Türk Lirası iken, 22.07.2020 tarihinde yürürlüğe giren 7251 sayılı Kanunun 58/2. maddesiyle beşyüzbin Türk Lirası olarak değiştirilmiştir.

19 Ticarî davalar hakkında genel bilgi için bkz. Mine Akkan, 'Asliye Ticaret Mahkemeleri' iç Hakan Pekcanıtez, Muhammet Özekes, Mine Akkan ve Hülya Taş - Korkmaz (edr), Pekcanıtez Usûl Medenî Usûl Hukuku (15. Bası, Oniki Levha Yayıncılık 2017) 159 vd. Ayrıca genel olarak bkz. Levent Börü ve İlker Koçyiğit, Ticari Dava (2. Bası, Adalet Yayınları 2021). 
usûlüne göre dilekçelerin teatisinin gerçekleştirilmesi söz konusu olacaktır. Yine Kanun metninde öngörülen değerin altındaki ve üzerindeki uyuşmazlıkların objektif dava yığılması şeklinde tek bir yargılama prosedürüne konu edilmesi hâlinde, taleplerin bir arada incelenmesinin bazı zorluklar yaratması da kaçınılmazdır ${ }^{20}$. TTK’nin 4/2. maddesi, yargılama usûlüne ilişkin değer sınırını getirmekle yetinmiş; bu kurala herhangi bir istisna öngörmemiştir. Yine doğabilecek usûlî sorunlara ilişkin özel hükümler de düşünülmemiştir. Belirtmek gerekir ki belirsiz alacak davasında kesin talep sonucunun mahkemeye bildirildiği ve diğer davalarda davanın ıslah edildiği yargılama kesiti göz önüne alındığında, gerek taraflarca verilecek dilekçelerin sayısı bakımından gerekse iddianın ve savunmanın genişletilmesi veya değiştirilmesi yasağı bakımından geçmişe etkili makûl bir çözüm getirilebilmesi mümkün görünmemektedir. Bu davalar bakımından yargılama usûlünün değere dayalı şekilde uygulanması isteniyorsa özel bir düzenleme ile yargılama usûlünün dava devam ederken değişmesi ihtimâlinin önüne geçmek yerinde olacaktır.

\section{III. “KÜÇÜK UYUŞMAZLIKLARIN (SMALL CLAIMS)" ÇÖZÜMÜNE DAIR MUKAYESELI HUKUKTAKI YARGILAMA USÛLLERINE VE ÖZEL PROSEDÜRLERE GENEL BİR BAKIŞ}

\section{A. GENEL OLARAK}

Pek çok ülke hukukunda, belirli değerin altındaki uyuşmazlıkların çözümü için gerek mahkeme organizasyonu bakımından gerekse yargılama usûlü bakımından özellik arz eden durumlar mevcuttur. $\mathrm{Bu}$ yöndeki düzenlemelerin temel amacı, belirli değerin altındaki uyuşmazlıklar bakımından daha az masraflı ve daha hızlı bir yargılama prosedürü gerçekleştirilmesi; bu şekilde de gerek adalete erişimin etkin temini gerekse mahkemelerin iş yükünün azaltılması olmaktadır. Hukukumuzda belirli değerin altındaki uyuşmazlıkların çözümüne tek uygulama örneği, tüketici hakem heyetleridir. Bununla birlikte, tüketici uyuşmazlığı olmayan küçük uyuşmazlıklar bakımından da yazılı yargılama usûlünün uzun ve nispeten masraflı uygulamasının sorunlar yarattığı görülmektedir.

2013 yllında, Avrupa Birliği Komisyonu için hazırlanan karşlaş̧ırımalı bir araştırmaya göre, AB’ye üye 21 ülkede küçük uyuşmazlıkların çözümü için özel prosedürler bulunmaktadır. Bu ülkelerde, "küçük uyuşmazlıklar (small claims)" olarak nitelendirilen uyuşmazlık değerleri, 600,00 Avro (Almanya) ile 25.000,00 - Avro (Hollanda) ${ }^{21}$ arasında değişmektedir. Ortalama ise 4.400,00 - Avro olarak belirtilmiştir. Yine, ülkeden ülkeye bu uyuşmazlıklar için öngörülen prosedürler çeşitlenmektedir. Örneğin, Almanyåda hâkimin uyuşmazlığı daha az şeklî bir prosedüre tâbi şekilde çözümlemesine olanak sağlayan özel bir hüküm getirmekle yetinilirken; Polonya ve İngiltere örneklerinde, delillerin sunulması ve kanun yoluna başvuru gibi hususlara dair özel hükümler içeren bütüncül bir prosedür getirilmiştir²2.

20 Alman hukukunda, birbirinden farklı yargılama usûllerine tâbi taleplerin bir arada ileri sürülebileceği ifade edilmektedir. Bkz. Friedrich Stein and Martin Jonas, Kommentar zur Zivilprozessordnung (4. Band, $\$ \$ 253-327,22$. Aufl., Mohr Siebeck 2008) $\$ 260$, Rdnr.23.

21 İsviçre’de ise değer limiti 30.000,00 - İsviçre frangı olarak belirlenmiştir. Bkz. sZPO $\$ 243$.

22 Hırvatistan ve Danimarka bu çalışma kapsamına alınmamıştır. Çalışma için bkz. Rafal Mańko, European Small Claims Procedure - Legal Analysis of the Commission's Proposal to Remedy Weaknesses in the Current System (EPRS 2014) 4. 
Çalışmanın takip eden kısmında, prosedür çeşitliliğini daha iyi ortaya koyabilmek üzere seçilen bazı ülkelerdeki küçük uyuşmazlık çözüm prosedürleri kısaca tanıtılacak; sonrasında ise bu prosedürlerin öne çıkan yanları ayrı bir başlı altında değerlendirilecektir.

\section{B. BELIRLi DEĞERIN ALTINDAKI UYUŞMAZLIKLARIN BASIT YARGILAMA USÛLÜ DÂHILINDE ÇÖZÜMLENDIĞi BAZI MUKAYESELI HUKUK SISTEMLERININ TANITILMASI}

Gerek İsviçre gerekse Almanya'da, belirli değerin altındaki uyuşmazlıklar için basit yargılama usûlü (vereinfachte Verfahren) ya da Bagatellverfahren imkânları mevcuttur. Bununla birlikte, bu uyuşmazlıklar için ayrı ve bütüncül bir prosedür öngörülmüş değildir. Bu başlık altında, her iki ülkedeki ilgili sistemler genel hatlarıla tanıtılacaktır.

\section{I. isViçRE}

İsviçre'de sZPO $\$ 243$ hükmü ile, 30.000,00 - İsviçre frangına kadar olan davalarda basit yargılama usûlünün uygulanacağı; kantonal düzeydeki ticarî uyuşmazlıklar için kurulan özel mahkemelerde (ticaret mahkemesi) ise bu değer sınırının uygulanmayacağı düzenlenmiştir.

Basit yargılama usûlünün uygulandığı davalar, bir formun doldurulması şeklinde ya da sözlü şekilde açılabilmektedir (sZPO $\$ 244 / 1$ ). Dava açılırken, davanın tarafları, talep sonucu, dava konusu, gerekliyse dava değeri bildirimi, tarih ve imza hususlarını içeren bir başvuru yapilabilmektedir $($ sZPO $\$ 244 / 1-a, b, c, d, e)$. Davanın gerekçelendirilmesine ise gerek yoktur (sZPO $\$ 244 / 2)$.

Dava açlırken dava sebepleri bildirilmemiş ise, mahkeme, durumu davalıya bildirir ve bir duruşma günü belirler (sZPO $\$ 245 / 1$ ). Dava sebepleri bildirilmiş ise, mahkeme, yazılı beyanda bulunması için davalıya süre verir $($ sZPO $\$ 245 / 2)$.

Mahkeme, uyuşmazlı̆̆ın olabildiğince hızlı şekilde çözümlenmesi için gerekli tedbirleri alır (sZPO $\$ 246 / 1)$. Mahkeme, taraflardan vakıalar hakkındaki eksik bilgilerin tamamlanmasını ve ispat araçlarının gösterilmesini ister (sZPO $\$ 247 / 1)$.

\section{ALMANYA}

Almanya’da, dZPO \$ 495a düzenlemesi ile, değeri 600,00 - Avro tutarının altnda olan uyuşmazlıklar bakımından mahkemeye (Amtsgericht) bir takdir yetkisi tanınmış; bu uyuşmazlıkların Bagatellverfahren dâhilinde çözümlenmesi imkânı getirilmiştir.

Hâkim, dZPO $₫ 495$ a kapsamındaki takdir yetkisini, usûl hukukunun amacı ve temel yargılama ilkeleri doğrultusunda kullanmak zorundadır. Örneğin, olağan yargılama usûlünün kurallarından muafiyet yalnızca taraflardan birisi için uygulanamaz ${ }^{23}$.

23 Christian Wollschläger, 'Bagatelljustiz? Eine rechtshistorische, rechtsvergleichende und empirische Untersuchung des 
$\$$ 495a hükmüne göre yapılan Bagatellverfahren dâhilinde, tarafın mahkemede (Amtsgericht) avukat olmayan bir kişi tarafından temsili mümkündür. Bu durum, anayasal açıdan bazı endişelerle öğretide eleştirilmektedir ${ }^{24}$.

Takdir edilecek olan yargılama şekli, bir taraftan uyuşmazlığın çabuk, basit ve ucuz şekilde çözümlenmesini; diğer taraftan, taraflara yeterli hukukî koruma sağlanmasını garanti etmelidir ${ }^{25}$. Mahkeme, taraflardan birinin talep etmesi hâlinde, sözlü yargılama yapmalıdır $(\$ 495 \mathrm{a} / 1)$. Taraflardan birinin duruşma talebinin olmaması hâlinde, yargılamanın dosya üzerinden yürütülmesi mümkündür ${ }^{26}$ ve ilk derece mahkemesi açıkça izin vermedikçe kanun yoluna başvurulamamaktadır ${ }^{27}$.

dZPO $\$ 495$ a hükmü, hâkimi sıkı ispat kurallarından kurtarmaktadır ${ }^{28}$. Örneğin, mahkeme, tanıkları bizzat dinlemek yerine, yazılı şekilde veya telefonla bilgi isteyebilir. Bununla birlikte, ispata muhtaç konular inceleme yapmadan geçiştirilemez; ispat ölçüsü de değişkenlik göstermez ${ }^{29}$. Yine mahkeme kararlarının tefhiminde kararın gerekçesine kural olarak yer verilmez ${ }^{30}$.

\section{BELIRLI DEĞERIN ALTINDAKI UYUŞMAZLIKLARIN KENDINE ÖZGÜ BIR PROSEDÜR DÂHILINDE ÇÖZÜMLENDIĞi BAZI MUKAYESELI HUKUK SISTEMLERININ TANITILMASI}

\section{INGILTERE VE GALLER}

İngiltere ve Galler'de, belirli bir değerin altındaki uyuşmazlıklar, küçük uyuşmazlık çözüm prosedürüne konu edilmektedir. Bununla birlikte, küçük uyuşmazlık çözüm prosedürünün uygulanması bakımından öngörülen değer limiti mutlak değildir ${ }^{31}$; tarafların kabulü ya da davanın basit nitelikte görülmesi durumlarında, değer limitinin üzerindeki uyuşmazlıklar da küçük uyuşmazlık çözüm prosedürüne konu edilebilmektedir. Aynı şekilde, değer limitinin altındaki uyuşmazlıkların karmaşık nitelikte olması durumunda, bunların standart yargılama prosedüründe

vereinfachten Verfahrens am Amtsgericht' in Erhard Blankenburg, Dieter Leipold and Christian Wollschläger (eds), Neue Methoden im Zivilverfahren (Bundesanzeiger 1991) 46-47; Sunar (n 3) 17. Bu takdir yetkisinin Federal Anayasa Mahkemesi içtihatlarında gelişen usûl hukukunun anayasal ilkeleri ile geniş ölçüde sınırlandırıldığı yönünde bkz. Mańko (n 8) 5.

24 Almanya'da dZPO $\$ 495$ a ile getirilmiş olan Bagatellverfahren ve anayasa hukuku açısından doğurduğu endişeler hakkında bkz. Joachim Hennrichs, 'Verfassungswidrigkeit des neuen $\$ 495$ a ZPO?’ (1991) 44 NJW 2815, 2815 vd.; Axel Kunze, Das Amtsgerichtliche Bagatellverfahren nach $\$ 495$ a ZPO (Ernst und Werner Gieseking 1995); Hubert Rottleuthner, 'Umbau des Rechtsstats? Zur Entformalisierung des Zivilprozesses im Bereich der Bagatellverfahren' (1996) 38 NJW 2473,2473 vd.; Othmar Jauernig and Burkhard Hess, Zivilprozessrecht (30. Aufl. C.H. Beck 2011) \$69 II 4; Eberhard Schilken, Zivilprozessrecht (7. Aufl. Vahlen 2014) Rdnr.772.

25 Bruno Bergerfurth, 'Das Neue ‘Bagatellverfahren’ nach $\$ 495$ a ZPO’ (1991) 15 NJW 961, 962; Sunar (n 3 ) 17.

26 Schilken (n 10) Rdnr.375.

27 Mańko (n 8) 5.

28 Serbest ispat (freibeweis) ve sıkı ispat (strengbeweis) hakkında bkz. Yavuz Alangoya, M. Kâmil Yıldırım ve Nevhis Deren - Yıldırım, Medenî Usul Hukuku Esasları (7. Bası Beta 2009) 295.

29 Sunar (n 3) 18.

30 Schilken (n 10) Rdnr.598.

31 Access to Justice - Final Report to the Lord Chancellor on the Civil Justice System in England and Wales, London 1996, s. $22 \mathrm{vd}$. 
çözümlenmesi mümkündür. Bu yönde bir karar, küçük uyuşmazlık çözüm prosedürüne başlandıktan sonra da alınabilir ${ }^{32}$.

Küçük uyuşmazlık çözüm prosedürü, değer limitinin altındaki karmaşık nitelik taşımayan davalar için hızlı ve düşük masraflı bir yargılama usûlü öngörmektedir. Küçük uyuşmazlıkların çözümü için özel bir mahkeme bulunmamaktadır; bu uyuşmazlıklar da asliye mahkemelerinde (county courts) çözümlenmektedir. Bu prosedürde, yargılama masraflarının davayı kaybeden tarafa yükletilmesine ilişkin kurallar sınırlandırılmıştır. Kazanan taraf her türlü yargılama masrafının tazmini talebinde bulunabilir; ancak, hukukî danışmaya ilişkin masraflar, en çok 260,00 - İngiliz sterlini tutarında olmak üzere sadece belirli davalarda talep edilebilmektedir. Bilirkişi ücreti gibi masraf kalemleri de sınırlandırılmıştır. Tüketici uyuşmazlıkları, ciddi yaralanmalar içermeyen kazalara ilişkin tazminat davaları, kira ilişkisinden kaynaklanan uyuşmazlıklar gibi karmaşık nitelik göstermeyen davalar bu prosedür dâhilinde çözümlenmektedir. Tarafların rıza göstermelerine bağlı olmaksızın, duruşma yapılmadan dosya üzerinden karar verilebilecektir. Bu prosedürde avukatla temsil zorunluluğu bulunmamaktadır; hâkim, yargılamayı tarafların anlayacağı şekilde yürütmelidir. Taraflar, kendilerini mahkemede temsil edecek ve onların adına konuşabilecek hukukçu olmayan bir temsilci de atayabilirler. Bu prosedürde, ispata ilişkin esnek kurallar mevcut olup mahkeme, prosedürün organizasyonu konusunda takdir yetkisini haizdir. Kural olarak, bilirkişi incelemesi de yapılmaz. Ancak, taraflardan birinin gerekli olduğunu ileri sürmesi ve mahkemenin izin vermesi hâlinde bilirkişi deliline başvurulabilir. Bu prosedürde, kural olarak, verilen kararlar hakkında kanun yoluna başvurulamamaktadır. Kanun yoluna başvurmak isteyen taraf, mahkemeye ikna edici gerekçeler sunmalı ve mahkemenin iznini almalıdır ${ }^{33}$.

$\mathrm{Bu}$ prosedürde genel olarak mahkeme, davalının beyanlarından sonra, taraflara soru formları göndermektedir. $\mathrm{Bu}$ formların kısa sürede yanıtlanıp gönderilmesi gereklidir. Tarafların verdiği yanıtlar, davanın karmaşıklığı ve önemi konusunda mahkemeyi bilgilendirici nitelikte olmalıdır. Hâkim, bu bilgilere dayanarak uygulanacak yargılama usûlünü belirler. Yargılama usûlüne karar verecek olan mahkeme, davayı görecek olan mahkemedir ${ }^{34}$.

\section{FRANSA}

Küçük uyuşmazlıkların basitleştirilmiş bir usûl dâhilinde çözümlenmesi imkânı, Fransa'da 2002 yılında getirilmiş ve 2014 sonuna dek bu uygulama devam etmiştir ${ }^{35}$.

Fransa'da küçük uyuşmazlıklar için değer limiti 4.000,00 - Avro olarak belirlenmişti (article L 331-2 $\mathrm{CO}^{36}$ ). Davalar tek bir "hâkim" tarafından görülmekte ve kanun yolu imkânı bulunmamaktaydı. Yargı

32 Mańko (n 8) 5.

33 Stuart Sime, A Practical Approach to Civil Procedure (10. Ed. Oxford 2007) 328-329; Adrian Zuckerman, Zuckerman on Civil Procedure - Principles of Practice (Sweet \& Maxwell 2006) 486 vd.; Mańko (n 8$) 5$.

34 Sime (n 19) 190; Ayșe Gülin Güralp, Anglo-Amerikan ve Kita Avrupası Medenî Yargılama Hukuku Sistemleri’ndeki Reform Çalışmaları, Yeni Gelişmeler ve Türk Hukuku Bakımından Değerlendirilmesi (Oniki Levha Yayıncılık 2011) 181-182.

35 Catherine Elliott, Catherine Vernon and Eric Jeanpierre, French Legal System (2nd Ed. Pearson/Longman 2006) 8990, 173; Loic Cadiet, 'Civil Procedure' in A. George A. Bermann and Etienne Picard (eds), Introduction to French Law (Wolters Kluwer 2008) 311; Mańko (n 8) 5-6.

36 Code de lorganisation judiciaire (Adlî Teşkilat Kanunu). Kanunun Fransızca metni için bkz. https://wwwwlegifrance. 
yetkisi, "jurisdictions de proximité" olarak adlandırlan ve hâli hazırda görevli olan hâkimlerden değil; yedi yıllık bir süre için ve beş günlük bir eğitim neticesinde atanan avukatlar, emekli hâkimler ve hukuk fakültesindeki öğretim üyelerine devredilmekteydi. Beş günlük eğitim, mahkemede çalışma deneyimini de içermekteydi ve her yıl tekrarlanan birkaç saatlik eğitimler bulunmaktaydı. Ayrıca bu kişilerin 35 yaşından büyük olmaları şartı da bulunmaktaydı. Jurisdictions de proximité hâkimleri, işlerini yarı zamanlı olarak yapmaktaydı (haftada bir gün) ve çoğunlukla ayrı bir meslek dalında uzmanlıkları bulunmaktaydı ${ }^{37}$.

$\mathrm{Bu}$ mahkemelerin kuruluşuna dair pek çok kayda değer eleştiri bulunmaktaydı. Özellikle bu mahkemelerin adil bir şekilde hak dağıtımını yapma konusundaki kapasiteleri hakkında şüpheler bulunmaktaydı. Yine bu hâkimlere verilen eğitimlerin tamamen yetersiz olduğu da belirtilmekteydi. Conseil constitutionnel, bu itirazları 29.08.2002 ve 20.01.2005 tarihli iki kararıla reddetmiştir ${ }^{38}$.

Jurisdictions de proximité, davanın, uygulanacak hukuk kurallarının ya da taraflar arasındaki sözleşme hükümlerinin karmaşı olduğu kanaatindeyse, davayı yetkili mahkemeye gönderebilir. Jurisdictions de proximité, 2011 tarihinde yürürlükten kaldırılmış; ancak 2014 yllına dek hukuk davalarına bakmaya devam etmiştir ${ }^{39}$.

Hâli hazırda, Fransız Hukuk Muhakemeleri Kanunu’nun 756 ve devamı maddelerine göre, küçük uyuşmazlıkların çözümlenebilmesi mümkündür. Yargılama sözlü olarak gerçekleşmekle birlikte, taraflar isterlerse yazılı dilekçe de sunabilmektedirler. Kanunun 828. maddesi, yargılamanın herhangi bir aşamasında, tarafların anlaşması ile yargılamanın duruşma yapılmaksızın gerçekleştirilebileceğini düzenlemektedir. Hâkim, duruşma yapmaksızın karar verilmesinin mümkün olmadığıı kanaatindeyse ya da taraflardan birinin talebi olması hâlinde, duruşma yapılmasına karar verebilmektedir. Yine Kanunun 757. maddesinde de duruşma yapılmaksızın yargılama yapılmasına ilişkin imkândan bahsedilmektedir. Bu prosedür, 1 Ocak 2020 tarihinden beri yürürlüktedir. Yargılamadan önce, hâkim tarafından kabul görecek bir alternatif uyuşmazlık çözüm yöntemine başvurulmuş olması da gerekmektedir. Avukatla temsil zorunluluğu bulunmamakta ve taraflar, eşleri, birlikte yaşadıkları partnerleri, akrabaları ya da çalışanları gibi kişiler tarafından yargılamada temsil edilebilmektedir. Değer sınırı ise 5.000,00 - Avro olarak belirlenmiştir. Değer sınırı nedeniyle kanun yoluna başvuru imkânı da mevcut değildir. Yargılama masrafları ve bu masrafların tazmini, olağan prosedürden farklı şekilde düzenlenmemiştir; bununla birlikte, avukatla temsil gerekli olmadığından bu masraflar daha düşük olmaktadır. Matbu bir formun doldurulması şeklinde dava açılabilmesi de mümkündür. İspata ve yargılamaya ilişkin diğer kurallar bakımından ise olağan yargılama usûlünden farklı bir düzenleme bulunmamaktadır ${ }^{40}$.

gouv.fr/codes/texte_lc/LEGITEXT000.006.071164/?isSuggest=true

37 Elliott, Vernon and Jeanpierre (n 35) 90.

38 ibid 90.

39 Mańko (n 8) 6.

40 Fransız Hukuk Muhakemeleri Kanunu’nun Fransızca metni için bkz. https://www.legifrance.gouv.fr/download/pdf/ legiOrKali?id=LEGITEXT000.006.070716.pdf\&size=796,2\%20Ko\&pathToFile=/LEGI/TEXT/00/00/06/07/07/16/ LEGITEXT000.006.070716/LEGITEXT000.006.070716.pdf\&title=Code\%20de\%20proc\%C3\%A9dure\%20civile Ayrica bkz. https://e-justice.europa.eu/42/EN/small_claims?FRANCE\&member=1 


\section{HOLLANDA}

Hollanda'da 1991 tarihinden bu yana küçük uyuşmazlıkların basitleştirilmiş bir prosedür dâhilinde çözümlenmesi imkânı mevcuttur ${ }^{41}$.

Değer limiti, başlangıçta 5.000,00 - Avro olarak belirlenmişken; adalete erişimin artırılması amacıyla, 1 Temmuz 2011'den itibaren uygulanmak üzere, 25.000,00 - Avro tutarına yükseltilmiştir. Buna ek olarak, tüm tüketici satışlarının yanı sıra, 40.000,00 - Avro tutarına kadar olan tüketici kredisi davaları için de yargı yetkisi bulunmaktadır. Böylelikle, küçük uyuşmazlık çözüm prosedürünün kapsamı genişlemiş ve esas başvuru mekanizmasına dönüşmüştür ${ }^{42}$.

Bu prosedürün olağan yargılama prosedüründen temel farkları, şekliliğin azaltılması, avukatla temsil mecburiyetinin olmaması ve dilekçeler değişiminden ziyade sözlü yargılamaya yoğunlaşılması şeklinde özetlenebilir. Bununla birlikte, tüm prosedürün yazılı şekilde yürütülmesi de olağan dışı bir durum değildir. Yargı yetkisi, iş hukukuna ilişkin uyuşmazlıklar ile kira ilişkisinden kaynaklanan uyuşmazlıkları çözümleyen, yerel mahkemenin alt bölge dairelerine devredilmiştir ${ }^{43}$.

\section{POLONYA}

Polonya’da 2000 yılından bu yana küçük uyuşmazlıklar basitleştirilmiş bir prosedür dâhilinde çözümlenmektedir. Değer limiti 10.000,00 - Polonya zlotisi (yaklaşık 2.400,00 - Avro) olarak belirlenmiş olmakla birlikte, talebin konusuna dayalı istisnalar da mevcuttur. Örneğin, fikrî mülkiyete dayalı uyuşmazlıklar, değer limitinin altında olsa bile bu prosedür dâhilinde çözümlenmez. Yine alıcınım satış sözleşmesine dayalı taleplerinde, 10.000,00 - Polonya zlotisi tutarındaki değer limiti, talebin tutarı göz önünde bulundurulmaksızın satış sözleşmesinin değerine göre hesaplanmaktadır. Örneğin, 50.000,00 - Polonya zlotisi tutarındaki bir araç satışında satıcıdan sadece 2.000,00 Polonya zlotisi tutarında bir talepte bulunuluyorsa basitleştirilmiş prosedür uygulanmayacaktır. Nitekim, satış sözleşmesindeki bedel değer limitinin üzerindedir ${ }^{44}$.

Basitleştirilmiş prosedür, pek çok açıdan olağan prosedürden ayrılmaktadır. Bu prosedürde, iddialar ve savunmalar matbu formlar aracılığıly ileri sürülmelidir. Yargılama giderleri, olağan prosedüre göre düşüktür ${ }^{45}$. İspat kuralları da basitleştirilmiştir. Bilirkişi deliline ise başvurulamamaktadır.

41 Sandra E. Kramer and Elena Alina Ontanu, 'The Functioning of the European Small Claims Procedure in the Netherlands: Normative and Empirical Reflections' (2013) 3 Nederlands Internationaal Privaatrecht 319, 320; Mayer, Lindemann and Haibach (n 3) 18-20; Mańko (n 8) 6.

4229 Mayıs 2009 tarihli Kanun, No. 31 596: Uitvoeringswet verordening Europese procedure voor geringe vorderingen (Avrupa Küçük Uyuşmazlık Usûlü Tüzüğü Uygulama Kanunu). Kanunun Felemenkçe metni için bkz. https://wetten.overheid.nl/ BWBR0025914/2017-07-14. Ayrica bkz. Kramer and Ontanu (n 23) 320.

43 Kramer and Ontanu (n 23) 320; Mańko (n 8) 6.

44 Mańko (n 8) 6.

45 Olağan prosedürde yargılama harcı dava değerinin \%5’ine karşılık gelmekteyken, basitleştirilmiş prosedürde, 2000,00 - Polonya zlotisi tutarına kadar olan uyuşmazlıklarda 30,00 - Polonya zlotisi (yaklaşık 7,00 - Avro); 2000,00 - 5.000,00 Polonya zlotisi arasındaki uyuşmazlıklarda 100 Polonya zlotisi (yaklaşık 24,00 - Avro); 5.000,00 - 7.500,00 Polonya zlotisi arasındaki uyuşmazlıklarda 250,00 - Polonya zlotisi (yaklaşık 60,00 - Avro); 7.500,00 - 10.000,00 Polonya zlotisi arasındaki uyuşmazlıklarda 300,00 - Polonya zlotisi (yaklaşık 71,00 - Avro) yargılama harcı alınmaktadır. Bkz. Mańko (n 8) 7, fn.12. 
Değeri düşük olmasına rağmen, uyuşmazlık bilirkişiye başvurulmasını gerektirecek özellikte ise, mahkeme, davanın olağan prosedüre göre görülmesine karar verebilecektir. Kanun yoluna başvuru hâlinde, karar üç hâkim yerine tek hâkim tarafından denetlenmektedir. Taraflar, yalnızca talepleri hâlinde kanun yolu mahkemesince dinlenmektedir ${ }^{46}$.

\section{ISVEÇ}

İsveç่te 22.250,00 - İsveç kronu (yaklaşık 2.600,00 - Avro) değerine kadar olan uyuşmazlıklar, basitleştirilmiş prosedür dâhilinde çözümlenmektedir. Aile hukukuna dair talepler ise kapsam dışı bırakılmıştır ${ }^{47}$.

Prosedüre başvuru için özel formların kullanılması mecburî değildir; ancak her türlü hukuk uyuşmazlığı için kullanılabilecek bir model form da bulunmaktadır. Mahkeme, taraflardan birinin talep etmemesi ya da gerekli görmemesi hâlinde, duruşma yapılmamasına karar verebilmektedir. Yargılama giderlerine ilişkin kurallar da olağan yargılama prosedüründen farklıdır. Davayı kazanan taraf, gerekli olduğu için sağlanan çeviri ve seyahat giderlerinden başka, yalnızca bir saatlik hukukî danışmanlık ücretinin tazminini sağlayabilmektedir. Kanun yoluna başvuru ise mahkemenin izniyle mümkün olabilmektedir. Bu izin, davanın hukukun gelişimine etkisinin olabileceği ya da mahkeme kararının bozulması beklentisini oluşturacak sağlam gerekçelerin varlığı hâllerinde verilecektir. $\mathrm{Bu}$ prosedür için yargı yetkisi özel bir mahkemeye devredilmemiştir; olağan yargılama prosedüründeki mahkemeler uyuşmazlığı çözümlemektedir ${ }^{48}$.

\section{DEĞERLENDIRME VE SONUÇ}

Karşılaştırmalı hukuk sistemleri incelendiğinde, pek çok ülkede belirli değerin altındaki uyuşmazlıklar için olağan yargılama usûlünden vazgeçildiği görülmektedir. Bu tercihin motivasyonu, düşük değerdeki uyuşmazlıkların hızlı ve ucuz şekilde çözümlenebilmesi; bu şekilde de adalete erişimin kapsamının genişletilmesidir. Ayrıca, mahkemeler üzerindeki iş yükünün azaltılması da etkenlerden biri olarak değerlendirilebilir. Bununla birlikte, taraflara sağlanan hukukî himayenin de yeterli derecede olması gözetilmektedir.

Belirli değerin altındaki uyuşmazlıkların çözümü için karşılaştırmalı hukukta öngörülen sistemler, gerek değer limitleri (600,00 Avro - 25.000,00 Avro arasında değişkenlik göstermekle birlikte, ortalama 4.400,00 - Avro) gerekse prosedürün organizasyonu ve yapısı konusunda son derece çeşitlidir. Diğer bir ifadeyle, amaç aynı olmakla birlikte, bu amaca ulaşmak için kullanılan araçlar birden fazladır. Bununla birlikte, bu prosedürlerin temel ortak yönleri de bulunmaktadır. Bu ortak yönler şu şekilde sıralanabilir:

\footnotetext{
46 Mańko (n 8) 6-7.

47 Mayer, Lindemann and Haibach (n 3) 23-34; Mańko (n 8) 7 ..

48 Mańko (n 8) 7.
} 
1. Avukatla temsil mecburiyetinin olmaması

2. Duruşma yapılması mecburiyetinin sınırlandırılması

3. İddia ve savunmaların sunulması aşamasının çeşitli şekillerde hızlandırılması

4. Hâkimin prosedürün organizasyonu konusunda da takdir yetkisini haiz olması

5. İspat kurallarının basit ve esnek nitelikte olması ve kural olarak bilirkişi deliline başvurulamaması

6. Kanun yoluna başvurunun imkânının mevcut olmaması ya da mahkemenin izniyle sınırlı hâllerde olabilmesi

7. Yargılama masraflarının sinırlandırılması

Hukukumuzda, genel olarak, belirli değerin altındaki uyuşmazlıkların basitleştirilmiş bir prosedür dâhilinde çözümlenmesi imkânı mevcut değildir. Bunun göze çarpan örneği ise, tüketici hakem heyetleri uygulamasıdır. Bununla birlikte, bu heyetlerin yapısı göz önüne alındığında ${ }^{49}$, karşılaştırmalı hukuktaki düzenlemelere benzer olmadığı görülmektedir. Nitekim, karşılaştırmalı hukuk düzenlemelerinde prosedürün mahkeme tarafından yürütülmesi söz konusudur. Yalnızca Fransa'da bir süre uygulanan sistemde hâli hazırda hâkim olmayan kişiler karar verici pozisyonunda olmuştur. Bununla birlikte, bu kişiler avukatlar, emekli hâkimler ya da hukuk fakültesindeki öğretim üyeleri arasından seçilmiştir. Diğer bir ifadeyle, prosedür basitleştirilmekle birlikte karar verici pozisyonda olan kişiler konusunda esneklik gösterilmemiştir. Bununla birlikte, tüketici hakem heyeti kararlarının itiraz üzerine tüketici mahkemesince denetlenebilmesi, başvurucuların bir noktada hâkim önünde iddia ve savunmalarını ileri sürebilmelerini temin ederek adalete erişimi bir ölçüde sağlayabilmektedir. Tüketici hakem heyeti uygulaması, anayasal temeli haiz usûlî garantileri tam olarak sağlayamamaktadır ve bu garantilere zarar vermektedir. Bu durum, hukukun uygulanması bakımından medenî yargılamanın araçsallaştırılmasına neden olmaktadır ${ }^{50}$.

Tüketici uyuşmazlıkları dışındaki uyuşmazlıklariçin ise benzer bir prosedürden bahsedilememektedir. Yalnızca TTK’nin 4/2. maddesindeki değeri beşyüzbin Türk Lirası altında olan ticarî uyuşmazlıklarda basit yargılama usûlünün uygulanacağına ilişkin münferit kural karşımıza çıkmaktadır.

Hukukumuzda yargılamaların uzun sürmesi ve düşük değerli talepler bakımından yargılama masraflarının davacı tarafından tolere edilememesi adalete erişimin önünde derin bir engel olarak karşımıza çıkmaktadır. Yine mahkemelerin iş yükü de büyük bir sorun teşkil etmektedir. Bu nedenle, belirli bir değerin altındaki uyuşmazlıkların basitleştirilmiş bir prosedür dâhilinde ve olabildiğince masraflar sınırlandırılarak çözümlenmesi bir gerekliliktir. İlgili uyuşmazlıklar için basit yargılama usûlünün uygulanmasına dair genel düzenlemenin de yeterli olmayacağı açıktır. Nitekim basit

49 Tüketici hakem heyetinin organizasyonu ile ilgili detaylı bilgi için bkz. Mehmet Kâmil Yıldırım, 'Die prozessualen Regelungen des neuen türkischen Verbraucherschutzgesetzes' in Christoph Althammer and Herbert Roth (eds), Instrumentalisierung von Zivilprozessen (Mohr Siebeck 2018) 62. Karş. EU-Richtlinie 2013/11 (Erwägungsgrund/ Gerekçe 4, 6).

50 ibid 78. 
yargılama usûlü ile, yazılı yargılama usûlüne nazaran, yukarıda sayılan amaçları gerçekleştirmeye yarar avantajlar temin edilememektedir.

Kanaatimizce, belirli değerin altındaki uyuşmazlıklar bakımından sulh mahkemelerinin görevlendirilmesi ${ }^{51}$; bununla birlikte, bu uyuşmazlıkların kendine özgü bir prosedür dâhilinde çözümlenmesi yerinde olacaktır. Öngörülen prosedür, hâkimin organizasyon konusunda takdir yetkisini haiz olduğu; iddiaların matbu formlar aracıllğıyla sunulduğu; sözlü yargılamaya ağırlık verilen; tarafların kendilerini avukat olmayan kimseler aracılı̆̆ıyla da temsil ettirebildiği; ispat kuralları konusunda esnekliğin tanındığı; bilirkişi deliline başvurulamayan; yargılama masraflarının sinırlandırıldığı ve mahkemenin kesin olarak karar verdiği ya da izne bağlı kanun yolunun mevcut olduğu bir prosedür olarak plânlanabilir. Prosedür için öngörülen değer limiti ile senetle ispat sınırı arasında bir paralellik sağlanması da bir an için düşünülebilir. 2021 yılı için bu sınır 4.480,00 - TL tutarındadır. Böylelikle sahtelik iddiaları için bilirkişi deliline başvurulması gerekliliği de belirli ölçüde tolere edilebilecektir. Buna karşın, prosedür dâhilinde kalacak uyuşmazlıklarda adalete erişimin kapsamının genişletilebilmesi için bu sınırın daha yüksek belirlenmesi uygun olacaktır.

\section{KAYNAKÇA}

Access to Justice - Final Report to the Lord Chancellor on the Civil Justice System in England and Wales, London 1996.

Akkan M., 'Asliye Ticaret Mahkemeleri' iç Hakan Pekcanıtez, Muhammet Özekes, Mine Akkan ve Hülya Taş Korkmaz (edr), Pekcanitez Usûl Medenî Usûl Hukuku (15. Bası, Oniki Levha Yayıncllı 2017).

Akkaya T., 'Temyize Başvuru Hakkının Sınırlandırılması ve İzne Bağlı Temyiz Sistemi', iç Osman Berat Gürzumar (ed), Halûk Konuralp Anısina Armağan (Yetkin Yayınları 2009).

Akkaya T., Medenî Usûl Hukuunda İstinaf (Yetkin Yayınları 2009).

Aktepe-Artık S., Medeni Usul Hukukunda Adil Yargılanma Hakkı (Seçkin Yayıncılık 2013).

Alangoya Y., 'Kanun Yolunun Anayasal Temeli ve HUMK m.427 Hükmü ile Kanun Yolu Kapatılmış Olan Kararlara Karşı Kanun Yoluna Müracaat İmkani’' iç Hakan Pekcanıtez (ed), 75. Yaş Günü İçin Prof. Dr. Baki Kuru Armağanı (Türkiye Barolar Birliği Yayınları 2004).

Alangoya Y., Yıldırım M. K. ve Deren - Ylldırım N., Medenî Usul Hukuku Esasları (7. Bası Beta 2009).

Bergerfurth B., ‘Das Neue ‘Bagatellverfahren’ nach $₫ 495 a$ ZPO' (1991) 15 NJW 961.

Bilge N. ve Önen E., Medenî Yargılama Hukuku Dersleri (Sevinç Matbaası 1978).

Börü L. ve Koçyiğìt İ., Ticari Dava (2. Bası, Adalet Yayınları 2021).

Cadiet L., 'Civil Procedure' in A. George A. Bermann and Etienne Picard (eds), Introduction to French Law (Wolters Kluwer 2008).

Elliott C., Vernon C. and Jeanpierre E., French Legal System (2nd Ed. Pearson/Longman2006)

Güralp A. G., Anglo-Amerikan ve Kita Avrupası Medenî Yarglama Hukuku Sistemleri’ndeki Reform Çalışmaları, Yeni Gelişmeler ve Türk Hukuku Bakımından Değerlendirilmesi (Oniki Levha Yayıncılık 2011).

51 Sulh hukuk mahkemeleri ile asliye hukuk mahkemeleri ayrımından ve bu ayrımı temel alan yazılı yargılama usûlü ve basit yargılama usûlü ayrımının gereklerinden yararlanılarak yargılamanın makûl sürede bitirilmesi amacıyla görev tayininde yeniden dava konusunun değerinin esas alınması gerektiği yönünde bkz. Süha Tanrıver, 'Sulh Hukuk - Asliye Hukuk Mahkemesi Ayrımının Anlam ve Önemi Üzerine Bazı Düşünceler', (2013) 105, Türkiye Barolar Birliği Dergisi $35-50,47$. 
Hennrichs J., 'Verfassungswidrigkeit des neuen §495a ZPO?' (1991) 44 NJW 2815.

Jauernig O. and Hess B., Zivilprozessrecht (30. Aufl. C.H. Beck 2011).

Kramer S. E. and Ontanu E.A., 'The Functioning of the European Small Claims Procedure in the Netherlands: Normative and Empirical Reflections' (2013) 3 Nederlands Internationaal Privaatrecht 319.

Kunze A., Das Amtsgerichtliche Bagatellverfahren nach \$495a ZPO (Ernst und Werner Gieseking 1995).

Mańko R., European Small Claims Procedure - Legal Analysis of the Commission's Proposal to Remedy Weaknesses in the Current System (EPRS 2014).

Mayer H. P., Lindemann J. and Haibach G., Small Claims Verordnung (C.H. Beck 2009).

Musielak H. J., Grundkurs ZPO (10. Aufl. 2010).

Özbek M. S., 'Avrupa Konseyince Adalet Hizmetlerinin Etkinliğinin Artırılması İçin Öngörülen Tedbirler', (2006) 55 (1) Ankara Üniversitesi Hukuk Fakültesi Dergisi 207-292.

Öztek S., 'HUMK m.427'deki Kesinlik Sınırının Temyiz Kanun Yolunun Amacı Bakımından Değerlendirilmesi ve Anayasa Mahkemesinin 10.1.1986 Tarihli Kararı', (1987) 21 (2), Marmara Üniversitesi Hukuk Araştırmaları Dergisi 62-74.

Öztek S., Türk Medeni Yargılama Hukukunda İstinaf ve Temyiz (Yetkin Yayınları 2021).

Pekcanıtez H., 'Medenî Usûl Hukukuna İlişkin Genel Bilgiler' iç Hakan Pekcanıtez, Muhammet Özekes, Mine Akkan ve Hülya Taş - Korkmaz (edr), Pekcanıtez Usûl Medenî Usûl Hukuku (15. Bası, Oniki Levha Yayınc1lı 2017).

Rickli S., Der Streitwert im schweizerischen Zivilprozessrecht (Dike 2014).

Rottleuthner H., 'Umbau des Rechtsstats? Zur Entformalisierung des Zivilprozesses im Bereich der Bagatellverfahren' (1996) 38 NJW 2473.

Sayar İ. B., 'Avrupa Basit Hak İddiaları Prosedürü (European Small Claims Procedure): Kapsamı ve Uygulanması Üzerine Bir İnceleme', (2018) XXII (1), Ankara Hacı Bayram Veli Üniversitesi Hukuk Fakültesi Dergisi 49-94.

Schilken E., Zivilprozessrecht (7. Aufl. Vahlen 2014).

Sime S., A Practical Approach to Civil Procedure (10. Ed. Oxford 2007).

Stein F. and Jonas M., Kommentar zur Zivilprozessordnung (4. Band, \$\$ 253-327, 22. Aufl., Mohr Siebeck 2008).

Sunar G., 'Medeni Usul Hukukunda Basit Yargilama Usulü' (Doktora Tezi, Marmara Üniversitesi 2002).

Sungurtekin-Özkan M., 'Anayasal Şikayet ve Adalete Erişim', (2014), 16 (Özel Sayı) Dokuz Eylül Üniversitesi Hukuk Fakültesi Dergisi (Prof. Dr. Hakan PEKCANITEZ’e Armağan) 399-410.

Tanrıver S., 'Sulh Hukuk - Asliye Hukuk Mahkemesi Ayrımının Anlam ve Önemi Üzerine Bazı Düşünceler', (2013) 105, Türkiye Barolar Birliği Dergisi 35-50.

Üstündağ S., 'Mukayeseli Hukukta Yargıtay Örnekleri ve Türk Yargıtayı', (1989) 15 (1-4), Yargıtay Dergisi 73 vd. Wollschläger C., 'Bagatelljustiz? Eine rechtshistorische, rechtsvergleichende und empirische Untersuchung des vereinfachten Verfahrens am Amtsgericht' in Erhard Blankenburg, Dieter Leipold and Christian Wollschläger (eds), Neue Methoden im Zivilverfahren (Bundesanzeiger 1991).

Yıldırım M. K., Hukuk Devletinin Gereği: İstinaf (Nesil Matbaacılık 2000).

Yıldırım M. K., 'Teksif ve Sözlülük İlkeleri Açısından Yargılama Usulleri Hakkında Düşünceler' iç Selçuk Öztek, M. Kamil Yıldırım ve Nevhis Deren - Yıldırım (edr), Prof. Dr. Ergun ÖNEN’e Armağan (Alkım 2003).

Yıldırım M. K., 'Die prozessualen Regelungen des neuen türkischen Verbraucherschutzgesetzes' in Christoph Althammer and Herbert Roth (eds), Instrumentalisierung von Zivilprozessen (Mohr Siebeck 2018).

Zuckerman A., Zuckerman on Civil Procedure - Principles of Practice (Sweet \& Maxwell 2006). 